\title{
LAJU PERTUMBUHAN DAN TINGKAT EFISIENSI PEMELIHARAAN TERNAK AYAM KAMPUNG SUPER TERHADAP PENAMBAHAN PAKAN NON KONVENSIONAL Growth Rate and Efficiency Rate of Livestock Keeping Chicken Kampung Super Toward Addition Non Conventional Feed
}

\author{
Nur Prabewi, S.Pt, MP \& Junaidi Pangeran Saputra
}

\begin{abstract}
ABSTRAK
Pemanfaatan sifat keunggulan ternak ayam kampung super dalam adaptasi lingkungan, bahan pakan, ketahanan terhadap penyakit dan kemampuan mengkonversi pakan sederhana yaitu formula pakan yang sebagian besar berasal dari bahan pakan non konvensional terhadap laju pertumbuhan dan performan ayam kampung super. Tujuan penelitian ini adalah untuk mengetahui Laju Pertumbuhan dan Tingkat Effisiensi Pemeliharaan Ternak Ayam Kampung Super Terhadap Penambahan Pakan Non Konvensional.

Alat dan bahan yang digunakan dalam kegiatan penelitian kandang penelitian 6 unit terbagi menjadi 16 petak dan perlengkapannya, ayam kampung super sebanyak 80 ekor, 2). Desinfektan, 3). Bahan pakan yang terdiri dari konsentrat BR 2, jagung kuning giling, tepung ikan, bekatul, garam secukupnya dan pakan non konvensional yaitu tepung daun singkong dan isi rumen.

Metode pengambilan data penelitian dilaksanakan selama 8 minggu dari ternak ayam perlakuan sebanyak 80 ekor dengan parameter yang diamati adalah konsumsi pakan, bobot badan, konversi pakan Persentase karkas.

Rancangan penelitian yang digunakan adalah Rancangan Acak Lengkap (RAL) terdiri dari 4 perlakuan dengan pengulangan sebanyak 4 kali adalah $\mathrm{P}_{0}$ : Ransum ( Bekatul $20 \%$ + Jagung $55 \%$ + Tepung Ikan $25 \%$ ) tanpa penambahan pakan non konvensional $0 \%, \mathrm{P}_{1}$ : Ransum + Tepung daun singkong $15 \%, \mathrm{P}_{2}$ : Ransum + Tepung isi rumen sapi $15 \%$ , $\mathrm{P}_{3}$ Ransum +Tepung isi rumen sapi 7,5 \% + Tepung daun singkong 7,5\%. Metode analisis data dianalisis menggunakan Analyses Of Variance (ANOVA), bila terdapat perbedaan maka diuji lanjut menggunakan metode Duncan's New Multeple Rage Test (DNMRT).

Hasil penelitian menunjukkan bahwa penambahan bahan pakan konvensional pada ayam kampung super memberikan hasil yang berbeda nyata sangat nyata $(\mathrm{P}<0,01)$ terhadap konsumsi pakan dan memberikan hasil yang berbeda nyata nyata $(\mathrm{P}<0,05)$ terhadap bobot badan akhir, FCR, persentase karkas. Kesimpulan adalah Penambahan bahan pakan tepung daun singkong $7.5 \%$ dan tepung isi rumen $7.5 \%$ menghasilkan konsumsi 7893.75 gram/ekor, bobot badan akhir 2104.6 gram/ekor dan persentase karkas $76.25 \%$ merupakan laju pertumbuhan tertinggi, serta menghasilkan angka FCR yang lebih kecil atau tingkat efisiensi tertinggi dibanding dengan perlakuan lainnya.
\end{abstract}

Kata kunci: Bahan Pakan Non Konvensional, Ayam Kampung Super, Laju pertumbuhan , Tingkat Efisiensi. 


\begin{abstract}
Utilization of super chicken breeding characteristic in environmental adaptation, feed ingredients, disease resistance and simple feed conversion ability is feed formula which mostly come from non conventional feed ingredient to growth rate and super chicken chicken performance. The purpose of this study is to determine the rate of growth and the level of efficiency of chicken breeding Super Kampung Against Addition of Non Conventional Feed.

The tools and materials used in research activities of 6 units of research enclosure is divided into 16 plots and equipment, super chicken chicken as much as 80 tails, 2). Disinfectant, 3). Feed ingredients consisting of BR 2 concentrate, milled yellow maize, fish meal, bran, salt sufficiently and non-conventional feed, cassava flour and rumen contents.

Methods of research data retrieval conducted for 8 weeks from chicken cow treatment as much as 80 tail with parameters observed is feed consumption, body weight, feed conversion Percentage of carcass.

The research design used was Completely Randomized Design (RAL) consisted of 4 treatments with 4 repetitions were P0: Ransum (Bekatul 20\% + Corn 55\% + Flour Fish $25 \%)$ without addition of non conventional feed $0 \%, P 1$ : Rations $+15 \%$ cassava flour, P2: Rations + Cassava rumen flour 15\%, P3 Rations + Cassava rumen flour 7.5\% + Cassava flour 7.5\%. Data analysis method was analyzed using Analyses Of Variance (ANOVA), if there is difference then tested continued using Duncan's New Multeple Rage Test (DNMRT) method.

The results showed that the addition of conventional feedstock in super chicken gave significantly different significantly $(P<0.01)$ to feed consumption and gave significantly different $(P<0,05)$ to the final body weight, FCR, percentage of carcass. The conclusion is the addition of cassava meal material of $7.5 \%$ cassava and $7.5 \%$ rumen content flour resulting in consumption of 7893.75 gram / tail, final body weight 2104.6 gram / tail and $76.25 \%$ carcass percentage is the highest growth rate, and yield smaller FCR number or efficiency level highest compared to other treatment
\end{abstract}

Keywords: Non Conventional Feed Material, Super Village Chicken, Growth Rate, Efficiency Level.

\section{PENDAHULUAN}

Ayam Kampung Super merupakan hasil persilangan ayam pejantan Jawa dengan ayam ras petelur yang memiliki kualitas genetik tinggi dan telah mengalami pemuliabiakan sehingga performan dan laju pertumbuhannya lebih baik dari pada ayam jawa /ayam kampung yang ada ini. Dengan kondisi ciri khas atau sifat keunggulan yang dimiliki ternak ayam kampung super tersebut, maka untuk menggali guna memanfaatkan sifat keunggulan atau supernya dalam laju pertumbuhan akan kami manfaatkan untuk mengetahui tingkat kemampuan adaptasi ternak ayam kampung super terhadap formula pakan yang sebagian besar berasal dari bahan bahan pakan non konvensional terhadap laju pertumbuhan dan performan ayam kampung super.

1. Ayam Kampung Super

Produk ayam kampung mempunyai nilai gizi yang tinggi yaitu kandungan nutrisi ayam kampung lebih tinggi dibanding ayam ras (broiler), dagingnya mengandung 19 jenis protein dan asam amino, serta konsumsi daging ayam 
kampung lebih sehat karena kandungan kolesterolnya lebih rendah dibanding kolesterol pada ayam broiler ( Handoko ,2011).

\section{Bahan Pakan Non Konvensional}

Bahan pakan unggas non konvensional adalah bahan pakan yang berpotensi digunakan sebagai campuran pakan unggas karena tingkat ketersediaan yang tinggi diberbagai daerah lokal, mengandung zat zat makanan yang diperlukan oleh unggas dan kurang bersaing dalam penggunaan dengan manusia, tetapi belum banyak dimanfaatkan karena tidak tersebar secara merata pada semua daerah atau hanya daerah - daerah tertentu yang memilikinya, kandungan anti nutrisinya yang umum dimiliki dan harus diolah terlebih dahulu sebelum dapat digunakan sebagai bahan pakan unggas.

a. Daun Singkong

Gohl (1981) menyatakan bahwa daun singkong mengandung kurang lebih $27 \%$ protein kasar, $16 \%$ Serat Kasar, 81,5\% Bahan Kering, Energi metabolis $1991 \mathrm{Kkal} / \mathrm{kg}$ serta Lemak Kasar 7\%. Sedangkan penelitian Wadia (1989) menunjukkan penggunaan $5 \%$ tepung daun ubi kayu varietas faroka dalam ransum ayam pedaging periode awal memberikan pertambahan bobot badan yang tertinggi dibandingkan dengan penggunaan 10 dan $15 \%$.

b. Isi Rumen

Isi rumen merupakan hasil limbah ternak ruminant, adalah bahan pakan yang terdapat microorganisme rumen dan merupakan sumber vitamin B dan banyak mengandung protein akibat adanya pencernaan protein dalam rumen. Berdasarkan komposisi zat yang terkandung didalam isi rumen batas tertentu tidak akan menimbulkan akibat yang merugikan bila dijadikan bahan pencampur ransum berbagai ternak. Kandungan nutrisi isi rumen sapi 8,6 $\%$ Protein, 32,28 \% Serat Kasar , 1,18 \% Lemak Kasar, 2821,8 \% Kkal/kg dan 24,95 \% Abu. Jumlah bakteri didalam isi rumen banyak sekali, bakteri tersebut merombak selulosa dan pentosan ke dalam asam asam organik ( terutama asam acetat) dan kemungkinan dalam jumlah kecil ke dalam gula - gula sederhana. Mikroorganisme tersebut mencerna pula pati, gula, lemak, protein dan nitrogen bukan protein untuk membentuk mikrobia dan vitamin B (Widodo, 2004) . Hasil penelitian Sanjaya ( 1995) menunjukkan bahwa penggunaan isi rumen sapi dalam ransum sampai level $12 \%$ mampu meningkatkan pertambahan bobot badan dan konsumsi pakan ayam pedaging dan mampu menekan konversi pakan ayam pedaging.

\section{Jagung Kuning}

Jagung mempunyai kandungan energi metabolis $3.329 \mathrm{kkl} / \mathrm{kg}$, protein kasar 8,6\% dan kandungan serat kasarnya 2,5\% , (Retnani, 2002). Jagung kuning menghasilkan warna kuning pada kuning telur dan pada kaki, paruh dan kulit unggas, sedangkan jagung putih tidak. Hal tersebut sebagian disebabkan karoten yang terdapat dalam jagung kuning akan tetapi terutama disebabkan oleh xantofil. (Anggorodi 1985).

\section{Tepung Ikan}

Tepung ikan merupakan limbah industri pengolahan ikan dan sisa olahan pada waktu penangkapan. Limbah pengolahan ikan tersebut adalah bagian kepala, ekor, tulang dan buangan lainnya 
yang tidak digunakan (Limbah pengalengan sarden). Tepung ikan selain sebagai pangan nilai gizi tinggi bisa terjadi penghematan terhadap biaya produksi, karena peningkatan kadar protein sebanyak lebih dari empat kali (Widodo, 2004).

\section{Bekatul}

Bekatul merupakan sisa hasil penggilingan padi. Bekatul sangat baik diberikan pada ayam dan itik. Biasanya bekatul yang disimpan lama akan mudah diserang serangga dan berbau tengik. Agar kualitasnya tetap terjaga selama dalam penyimpanan, terlebih dahulu bekatul dikeringkan dibawah sinar matahari selama 3-4 jam setiap hari selama 3 hari berturutturut Sudoro dan Siriwa (2002) Bekatul mempunyai kandungan protein 10,2\%, energi metabolis $1.630 \mathrm{Kcal} / \mathrm{kg}$, lemak 7,9 $\%$, serat $8,2 \%$, (Nawawi dan Nurrohmah, 2003).

\section{Garam \\ Agus, (2007) menyatakan bahwa} Kandungan garam dapur adalah $\mathrm{NaCl}$ yang merupakan sumber $\mathrm{Na}$ dan $\mathrm{Cl}$. Garam dapur bersifat palatabel dan dapat menambah nafsu makan. Pemberian garam dapur adalah sebanyak $0.25 \%$ s/d $0.5 \%$ untuk campuran pakan ternak unggas. Siauwlielie (2012) menyatakan bahwa dalam formulasi pakan (unggas) biasanya dilakukan penambahan garam sebanyak 0,1 - 0,4\%. Mineral tersebut tidak disimpan dalam tubuh karena sebagian besar terdapat dalam cairan tubuh dan jaringan lunakKelebihan garam akan menyebabkan ayam minum berlebihan dalam upayanya untuk membuang kelebihan natrium keluar tubuh. Untuk fungsi normal, ayam membutuhkan $0,1-0,2 \%$ natrium.

\section{Konsumsi}

Sujionohadi dan Setiawan (2013) menyatakan bahwa pakan ayam kampung umur 3 s/d 4 bulan diberi pakan berupa pakan grower dan dedak, kebutuhan pakan per ekor dalam sehari $50 \mathrm{~s} / \mathrm{d} 60$ gram. Dengan perbandingan 1 bagian pakan grower dan 3 bagian dedak, selain itu perlu ditambahkan hijauan sekitar $20 \%$ dari total pakan yang diberikan. Diberikan dalam bentuk bubur berupa adonan bahan - bahan tersebut dengan air dan diberikan 2 kali sehari. Ayam kampung petelur dalam setiap $\mathrm{kg}$ berat badannya memerlukan $8 \mathrm{~g}$ protein, 3 g lemak dan 20 - 25 g karbohidrat. Kandungan protein sebaiknya divariasikan antara protein hewani dengan nabati, perbandingannya sekitar 1 ; 2 ( 1 bagian protein hewani dengan 2 bagian protein nabati). Pakan yang diperlukan oleh seekor ayam pada umur produktif yang berbobot 2 $\mathrm{kg}$ adalah sekitar $100 \mathrm{~g} / \mathrm{hari}$ dengan kandungan protein sekitar $16 \mathrm{~s} / \mathrm{d} 17 \%$.

\section{Konversi Pakan.}

Cahyono (2011) menyatakan bahwa angka konversi pakan ayam kampung sebesar 4.93 menunjukkan bahwa untuk menghasilkan 1 gram daging dibutuhkan 4.93 gram pakan. Selanjutnya Sarwono, (2011) menyatakan bahwa semakin baik mutu pakan, semakin baik konversinya. Cahyono (2011) menyatakan bahwa bahanbahan pakan sebaiknya harus digiling mengingat kebiasaan ayam mempunyai sifat memilih makanan yang berbentuk butiran tetapi kalau makanan yang terlalu halus maka tidak akan dikonsumsi seluruhnya oleh ayam. Sedangkan Sarwono (2011) menyatakan bahwa untuk menyusun pakan oplosan harus memperhatikan bahan pakan yang berkwalitas baik, tidak rusak (tengik,cendawan,banyak kutu), bahan pakan mudah didapat, harga murah ,tersedia secara kontinyu karena merupakan bahan pakan lokalita. 
9. Bobot Badan

Hasil penelitian Warasoma (2004) ayam kampung dipelihara selama 10 minggu dengan pakan mengandung protein $18 \%$ dan ME sebesar 2600 kkal/ kg menghasilkan rerata pertambahan bobot badan 792,64 g, rerata konsumsi pakan 2547 gram/ekor .Sedangkan menurut Krista dan Harianto (2012) menyatakan bahwa Ayam kampung pedaging konsumsi pakan selama 8 minggu menghabiskan pakan sejumlah 2.240 kg/ekor. Selanjutnya menurut Yaman (2013) menyatakan bahwa Ayam kampung pedaging unggul selama 6 minggu menghabiskan pakan sejumlah 2.3 $\mathrm{kg}$ dan bobot badan yang dihasilkan sekitar $1.4 \mathrm{~kg}$. Handoko (2011) menyatakan bahwa standar rata- rata performan ayam kampung umur 63 hari konsumsi pakan yang dihabiskan $2.23 \mathrm{~kg} / \mathrm{ekor}$ dan bobot badan yang dihasilkan rata - rata 975 gram/ekor.

\section{Karkas}

Karkas unggas adalah hasil pemotongan unggas (ayam) tanpa disertai darah, bulu, kepala, cakar (tulang metatarsus hingga jari-jari kaki), usus, dan giblet (hati, jantung, dan empedal), dan paru-paru masuk kedalam karkas karena sulit untuk dipisahkan (Yuwanta, 2004). Persentase karkas ayam adalah bobot tubuh ayam tanpa bulu, darah, kepala, kaki dan organ dalam (visceral) hati, jantung, dan ampela (giblet) dibagi dengan bobot hidup dikali $100 \%$. Faktor yang mempengaruhi berat karkas antara lain umur, galur, jenis kelamin, bobot badan, kualitas, dan kuantitas pakan (Soeparno, 1998).

\section{MATERI DAN METODE}

Alat yang digunakan dalam kegiatan penelitian meliputi : 1). Kandang penelitian 6 unit terbuat dari bambu \& kawat ram dengan ukuran P 2 M x L $1 \mathrm{M}, 2)$. Tempat pakan 12 buah terbuat dari bambu, 3). Tempat air minum 12 unit dengan kapasitas 1 liter,4). Lampu 25 watt sebanyak 12 buah untuk penerangan, 5). Hand sprayer 1 unit untuk penyemprotan kandang, 6). Timbangan elektrik 1 unit dengan kepekaan 0,1 gram untuk menimbang bobot hidup ayam

Bahan yang digunakan dalam kegiatan penelitian yaitu : 1). Ayam kampung super sebanyak 80 ekor, 2). Desinfektan, 3). Bahan Pakan yang terdiri dari BR2 1 sak, Jagung kuning Giling 175 Kg, Tepung Ikan $100 \mathrm{Kg}$, Bekatul 60 Kg, Tepung Daun Ketela Pohon $8 \mathrm{Kg}$, Isi Rumen $60 \mathrm{Kg}$, garam secukupnya. 4) Kapur, 5). lysol

\section{Metode pengambilan data}

Pengambilan data penelitian dilaksanakan dengan cara mencatat berbagai data yang diamati selama 8 minggu dari ternak ayam perlakuan sebanyak 80 ekor ke dalam blangko pada tiap tiap parameter secara keseluruhan meliputi Konsumsi pakan, Bobot badan, Konversi Pakan, Jangka waktu pemeliharaan, Persentase karkas.

\section{Rancangan penelitian}

Rancangan penelitian yang digunakan adalah Rancangan Acak Lengkap (RAL) terdiri dari 4 perlakuan dengan pengulangan sebanyak 4 kali sehingga diperoleh 16 petak kandang penelitian.

Petak kandang penelitian sesuai dengan perlakuan masing - masing yaitu

1. $\mathrm{T}_{0}$ Ransum ( Bekatul $20 \%+$ Jagung $55 \%+$ Tepung Ikan $25 \%$ ) tanpa penambahan pakan non konvensional $0 \%$

2. $\mathrm{T}_{1}$ Ransum dengan penambahan pakan non konvensional (Tepung daun singkong $15 \%$ )

3. $\mathrm{T}_{2}$ Ransum dengan penambahan pakan non konvensional (Tepung isi rumen sapi $15 \%$ ) 
4. $\mathrm{T}_{3}$ Ransum dengan penambahan pakan non konvensional (Tepung isi rumen sapi 7,5\% + Tepung daun singkong 7,5\%).

\section{Parameter yang diamati}

a. Konsumsi pakan dengan cara pakan ditimbang untuk kebutuhan satu minggu dan pada hari ke-7, sisanya ditimbang sehingga diketahui jumlah pakan yang dikonsumsi (g/ekor/minggu).

b. Bobot badan dengan cara menimbang ayam setiap ekor pada setiap perlakuan dan dilakukan setiap minggu (g/ekor/minggu)

c. Konversi pakan dihitung dengan cara membagi total konsumsi pakan dengan, total pertambahan bobot badan setiap minggu.

d. Persentase karkas, dengan cara memotong ayam dan karkas ditimbang, masing-masing perlakuan dipilih 2 ekor ayam untuk diketahui persentase karkas.

Persentase Karkas $=\frac{\text { Berat Karkas }}{\text { Bobot Hidup }} \times 100 \%$

\section{Analisis Data}

Data yang diperoleh dilakukan analisis menggunakan Analyses of
Variance (ANOVA), Jika dalam analisis tersebut terdapat perbedaan hasil perlakuan, maka untuk mengetahui perlakuan mana yang menunjukkan perbedaan analisis dilanjut menggunakan metode Duncan's New Multeple Rage Test (DNMRT), atas dasar 5\% "Level Of Significane"

\section{HASIL DAN PEMBAHASAN}

Hasil penelitian tentang Laju Pertumbuhan dan Tingkat Effisiensi Pemeliharaan Ternak Ayam Kampung Super Terhadap Penambahan Pakan Non Konvensional dengan sampel penelitian sebanyak 80 ekor selama 8 minggu mulai dari umur 8 minggu sampai dengan umur 16 minggu, memberikan hasil rerata konsumsi pakan, pertambahan bobot badan, konversi pakan dan persentase karkas yang terbagi 4 perlakuan yaitu: Perlakuan Kontrol (P0), Perlakuan Penambahan Tepung Isi rumen ( P1 ), Penambahan Tepung daun Singkong (P2 ) dan Penambahan campuran antara tepung daun singkong dengan tepung isi rumen, semua penambahan tersebut sebagai Pakan Campuran Ternak Ayam kampung super umur 8 minggu sampai 16 minggu yang disajikan pada Tabel 6.

Tabel 3. Rerataan hasil Penelitian dari setiap perlakuan

\begin{tabular}{lcccc}
\hline \hline \multirow{2}{*}{ Variabel } & \multicolumn{4}{c}{ Perlakuan } \\
\cline { 2 - 5 } & P0 & P1 & P2 & P3 \\
\hline Konsumsi pakan (gr/ekor) ** & $7772.5^{\mathrm{bc}}$ & $7796^{\mathrm{b}}$ & $7752.75^{\mathrm{bc}}$ & $7893.75^{\mathrm{a}}$ \\
Bobot badan akhir (gr/ekor) * & $1902.3^{\mathrm{ab}}$ & $2076.45^{\mathrm{a}}$ & $1965.25^{\mathrm{a}}$ & $2104.6^{\mathrm{a}}$ \\
Feed Conversion Ratio (FCR)* $^{\text {a }}$ & $4.09^{\mathrm{ab}}$ & $3.75^{\mathrm{a}}$ & $3.96^{\mathrm{ab}}$ & $3.75^{\mathrm{a}}$ \\
Persentase karkas * $^{\mathrm{ab}}$ & $68.75^{\mathrm{abc}}$ & $75^{\mathrm{a}}$ & $71.25^{\mathrm{ab}}$ & $76.25^{\mathrm{a}}$ \\
\hline
\end{tabular}

Supersekrip 'a,b.c, menunjukkan perbedaan level 5\% dan $1 \%$

Dari data tersebut dapat dilihat bahwa pada perlakuan ( P3 ) penambahan campuran antara tepung daun singkong 7,5 $\%$ dengan tepung isi rumen $7.5 \%$ menunjukkan angka tertinggi pada setiap parameter yang diamati yaitu konsumsi, bobot badan dan persentase karkas , sedangkan pada parameter konversi rasio 
menunjukkan angka paling kecil diantara tiga perlakuan lainnya yaitu P2, P1 dan P0, yang artinya pada perlakuan P3 yaitu penambahan campuran antara tepung daun singkong $7,5 \%$ dengan tepung isi rumen $7.5 \%$ menghasilkan angka 3.75 yaitu lebih kecil dari perlakuan lainnya sehingga dapat dikatakan bahwa tingkat efisiensi pakan dengan produk daging yang dihasilkan tertinggi diantara perlakuan lainnya.

\section{Konsumsi Pakan}

Hasil analisis variansi menunjukkan bahwa perlakuan tingkat penambahan pakan campuran antara tepung daun singkong 7,5\% dengan tepung isi rumen $7.5 \%$ dalam pakan berpengaruh sangat nyata ( $\mathrm{P}<0,01)$. terhadap konsumsi pakan. Rerata konsumsi pakan ayam kampung super selama 8 minggu pada perlakuan (P3) sebesar 7893,75 gram/ekor lebih tinggi dibandingkan perlakuan lainnya,hal ini dapat disebabkan karena adanya penambahan bahan pakan antara tepung daun singkong dengan tepung isi rumen pada perlakuan P3 dapat meningkatkan palatabilitas ternak ayam terhadap pakan sehingga konsumsi pakan yang masuk lebih banyak. Kondisi pakan pada perlakuan tepung daun singkong imbangan kandungan protein hewani dan nabati perbandingannya menuju ideal. Hal ini sesuai pendapat Setiawan (2013) menyatakan bahwa pakan ayam kampung pertumbuhan diberi pakan berupa pakan grower dengan kandungan protein sebaiknya divariasikan antara protein hewani dengan nabati, perbandingannya sekitar 1 ; 2 ( 1 bagian protein hewani dengan 2 bagian protein nabati).

\section{Bobot Badan akhir}

Hasil analisis variansi menunjukkan bahwa perlakuan tingkat penambahan pakan campuran antara tepung daun singkong $7,5 \%$ dengan tepung isi rumen
$7.5 \%$ dalam pakan berpengaruh nyata $(\mathrm{P}<$ 0,05) terhadap bobot badan akhir. Rerata bobot badan akhir ternak ayam kampung super umur 16 minggu pada perlakuan (P3) sebesar 2104.6 gram/ekor lebih tinggi dibandingkan perlakuan lainnya, hal ini dapat disebabkan karena pada perlakuan (P3) tepung daun singkong + tepung isi rumen, merupakan bahan nabati dan hewani sumber protein tinggi, untuk daun singkong disamping mengandung protein yaitu $25 \%$ juga dikenal mempunyai vitamin yang tinggi yaitu vitamin A yang aktif berkerja sama dengan zat lain dapat meningkatkan proses metabolisme tubuh dan memperbaiki jaringan sel sel tubuh, sedangkan kandungan isi rumen banyak mengandung bakteri dimana sel selnya dikenal mengandung protein yang tinggi, semasa hidupnya didalam rumen berfungsi merombak selulosa dan pentosan ke dalam asam asam organik ( terutama asam acetat), setelah isi rumen dimanfaatkan sebagai pakan, bakteri bakteri tersebut merupakan sumber protein pakan ternak, sehingga dapat meningkatkan bobot badan ternak ayam kampung. Hasil penelitian Sanjaya ( 1995) menunjukkan bahwa penggunaan isi rumen sapi dalam ransum sampai level 12 $\%$ mampu meningkatkan pertambahan bobot badan dan konsumsi pakan ayam pedaging dan mampu menekan konversi pakan ayam pedaging. Hasil rataan bobot badan dari ayam kampung super hasil penelitian perlakuan P0, P2 ( Tepung daun singkong $15 \%$ ), apalagi P3 (Tepung daun singkong $7.5 \%+$ Tepung isi rumen $7.5 \%$ ) dan P1 ( Tepung isi rumen 15\%) masih lebih tinggi lebih tinggi dibandingkan laporan hasil dari Yaman (2011) yang menyatakan bahwa perkembangan pada Ayam Lokal Pedaging Unggul (ALPU) sampai umur 16 minggu menghasilkan bobot badan berkisar 1561 - 1596 gram 


\section{Konversi Pakan (FCR)}

Hasil analisis variansi menunjukkan bahwa perlakuan tingkat penambahan pakan campuran antara tepung daun singkong $7,5 \%$ dengan tepung isi rumen $7.5 \%$ dalam pakan berpengaruh nyata $(\mathrm{P}<$ $0,05)$ terhadap konversi pakan ternak ayam kampung super. Rerata FCR ternak ayam kampung super umur 16 minggu pada perlakuan kontrol (PO) sebesar 4.09 tertinggi dibandingkan perlakuan lainnya.Hasil tersebut nilai FCR nya masih lebih kecil dibandingkan dengan pernyataan Handoko (2011) yang menyatakan bahwa kinerja ayam kampung yang dipelihara secara intensif sampai umur 18 minggu menghasilkan angka FCR sebesar 5.21. Nilai FCR yang baik atau dengan kata lain untuk mendapatkan hasil nilai (FCR) konversi pakan yang efisien sangat berhubungan dengan kwalitas pakan yang diberikan, tentunya nilai nutrisinya bagus, untuk itu bisa dikatakan bahwa pakan perlakuan (P1) dan perlakuan (P3) dapat menambah nilai nutrisi pakan sehingga meningkatkan kwalitas pakan dan kebutuhan nutrisi ternak bisa terpenuhi dengan baik. Hal ini sesuai pendapat Sarwono, (2011) menyatakan bahwa semakin baik mutu pakan, semakin baik konversinya. Sedangkan menurut Cahyono (2011) menyatakan bahwa angka konversi pakan sebesar 4.93 menunjukkan bahwa untuk menghasilkan 1 gram daging dibutuhkan 4.93 gram pakan.

\section{Persentase karkas}

Hasil analisis variansi menunjukkan bahwa perlakuan tingkat penambahan pakan campuran antara tepung daun singkong $7,5 \%$ dengan tepung isi rumen $7.5 \%$ dalam pakan berpengaruh nyata $(\mathrm{P}<$ $0,05)$. Rata-rata persentase karkas ternak ayam kampung super umur 16 minggu menunjukkan hasil pada perlakuan perlakuan P1 dan P3 lebih tinggi dari perlakuan lainnya yaitu $75 \%$ dan $76.25 \%$. Hasil tersebut menunjukkan bahwa perlakuan penambahan campuran antara tepung daun singkong $7.5 \%+$ tepung isi rumen $75 \%$ dan perlakuan penambahan isi rumen $15 \%$ sebagai bahan campuran ternak ayam kampung super dapat menambah nutrisi pakan yang dibutuhkan pada masa pertumbuhan ternak ayam, sehingga pertambahan bobot badan semakin lebih tinggi yang akhirnya menghasilkan persentase karkas yang lebih tinggi pula, hasil rataan persentase karkas dari perlakuan apabila dibandingkan rataan persentase karkas ternak ayam kampung asli yaitu rata rata $60 \%$ masih lebih tinggi tetapi persentase karkas tersebut dibawah angka persentase karkas menurut Yaman (2011) yang menyatakan bahwa Ayam Lokal Pedaging Unggul (ALPU) untuk yang jantan tipe berat menghasilkan persentase berat karkas sebesar $78.6 \%$. Sedangkan menurut Soeparno (1998) menyatakan bahwa faktor yang mempengaruhi berat karkas antara lain umur, galur, jenis kelamin, bobot badan, kualitas, dan kuantitas pakan.

\section{SIMPULAN DAN SARAN}

\section{Simpulan}

Penambahan bahan pakan campuran pakan antara tepung daun singkong $7.5 \%$ dan tepung isi rumen $7.5 \%$ menghasilkan konsumsi 7893.75 gram/ekor, bobot badan akhir 2104.6 gram/ekor dan persentase karkas $76.25 \%$ merupakan angka lebih tinggi dibandingkan perlakuan penambahan bahan pakan lainnya, serta menghasilkan angka FCR yang lebih kecil dibandingkan perlakuan penambahan pakan lainnya. Sedangkan pada perlakuan penambahan tepung isi rumen $15 \%$ termasuk mempunyai 
hasil rataan bobot badan akhir, konsumsi pakan, persentase karkas tinggi dibawahnya perlakuan penambahan campuran antara tepung daun singkong dan isi rumen, serta mempunyai nilai angka konversi yang sama dengan perlakuan penambahan campuran antara tepung daun singkong dengan tepung isi rumen yaitu 3.75 .

\section{Saran}

Ayam kampung super yang merupakan salah satu ternak unggulan hasil persilangan dari ayam kampung dengan ayam ras dimana sudah terbukti keunggulannya kecepatan pertumbuhannya, untuk itu sangat mendukung sekali dalam penyediaan daging ayam kampung sebagai daging olahan yang selama ini masih selalu kurang memenuhi permintaan, sehingga sebaiknya diadakan penelitian lebih lanjut lagi tentang penambahan bahan pakan yang kandunga gizi berkwalitas tetapi bahannya murah dan mudah didapat.

\section{DAFTAR PUSTAKA}

Agus, Ali. 2007. Membuat Pakan Ternak Secara Mandiri. PT Citra Aji Pratama, Yogyakarta.

Anggorodi, R, 1990. Ilmu Makanan Ternak. PT. Gramedia, Jakarta.

Cahyono B. 2011. Ayam Buras Pedaging, Cetakan Pertama, Penebar Swadaya Jakarta

Fadilah.R. dan Fatkhuroji, 2013. Memaksimalkan Produksi Ayam Ras Petelur.AgroMedia Pustaka. Jagakarsa,Jakarta.

Handoko B, 2011. Beternak Ayam Kampung, Dafa Publising, Jakarta.

Kholis S dan Sarwono B. 2013.Ayam Elba Kampung Petelur Super. Penebar Swadaya.Jakarta.
Krista.B dan Harianto.B, 2012. Petunjuk Praktis Pembesaran Ayam Kampung Pedaging. Penerbit Agromedia Pustaka.Jagakarsa, Jakarta.

Marjuki. A. (2012), Metode Cara Pembuatan Pakan Unggas. Httr// www. Ternak Ayam Kampung Cem/2012/11/ diakses tgl 5 Nopember 2012.

Murtijo, Bambang Agus. 1987. Pedoman Meramu Pakan Unggas. Kanisius, Yogyakarta.

Nawawi dan Nurrohmah, 2003. Ransum Ayam Kampung. Swadaya, Jakarta.

Nuroso, 2011. Ayam Kampung Pedaging Hari Per Hari. Penebar Swadaya, Bogor.

Parakkasi, A. 2006. Ilmu Nutrisi dan Makanan Ternak. Monograstrik. Universitas Indonesia, Jakarta.

Rasyaf, M. 2013. Beternak Ayam Kampung. Cetakan 3 Penebar Swadaya, Jakarta.

Retnani,Yuli. 2013. 6 Kunci Sukses Beternak Ayam Kampung Penebar Swadaya. Jakarta.

Retnani,Yuli.2002. Proses Produksi Pakan Ternak Ghalia Indonesia, Bogor

Sarwono B, 2011. Beternak Ayam Buras, Cetakan 33, Penebar Swadaya Jakarta.

Siawlielie, 2012. Garam . http://siauwlielie.tripod.com/art_0003.htm. Diakses tanggal 9 Maret 2013.

Steel R. G. and J. H. Torrie, 1991. Prinsip dan Prosedur Statistika. Gramedia Pustaka Utama, Jakarta.

Sudaryani.T dan Santoso.H, 2011. Panduan Lengkap Ayam. Penerbit Penebar Swadaya. Jakarta.

Sujionohadi K. dan Setiawan A.I, 2013. Ayam Kampung Petelur, Cetakan ke 33, Penebar Swadaya, Jakarta. 
Widodo,W.2004. Bahan Pakan Unggas

Konvensional Http// www. Pakan

Unggas/2013/02/ diakses tgl 15

Februari 2013.

Yahya M dan Hidayat T. 2013. Beternak

Ayam Kampung Di lahan

Sempit,Infra Pustaka

Yaman A. 2011. Ayam Kampung Unggul 6

Minggu Panen, Cetakan ke II

Penebar Swadaya Jakarta. 